\title{
Design, formulation and characterization of oral disintegrating tablets for lamotrigine
}

\begin{abstract}
Objective: The purpose of present investigation to formulate, characterize the oral dissolving tablets (ODT) for Lamotrigine. Lamotrigine, an antiepileptic agent, belongs to type -II as per Biopharmaceutical Classification System (BCS).

Methods: ODT formulations of Lamotrigine were prepared using different quantities of Sodium Starch Glycolate \& Crospovidone employed as Super disintegrants by Direct Compression technique. Nine trials were formulated and evaluated for Pharmaceutical Product Performance.

Results: Results shows that all the formulations were lie within the acceptance criterion and the In-vitro dissolution profiles were subjected to kinetic modeling.

Conclusion: Formulation $\left(\mathrm{F}_{4}\right)$ containing $35 \mathrm{mg}$ of Sodium Starch Glycolate \& $40 \mathrm{mg}$ of Crospovidone was found to be best one among all and also similar to the Marketed product (LAMICTAL-25) $\left(\mathrm{f}_{2}=73.17, \mathrm{f}_{1}=3.65\right.$ \& No significant difference, $\left.\mathrm{t}=0.0218\right)$ to marketed product. Formulation $\left(\mathrm{F}_{4}\right)$ follows First order, Higuchi's kinetics, mechanism of drug release was found to be Non-Fickian Diffusion $(\mathrm{n}=0.554)$.
\end{abstract}

Keywords: lamotrigine, super disintegrants, crospovidone, sodium starch glycolate sodium, wetting time, disintegration time, non-fickian diffusion
Volume 9 Issue 2 - 2020

\author{
Raghavendra Kumar Gunda,' Prasada Rao \\ Manchineni, ${ }^{2}$ Yerra Sai Sumanjali, ${ }^{3}$ Somepalli \\ Veeranjaneyulu, ${ }^{3}$ Penumula Ramanamma, ${ }^{3}$ \\ Tatikonda Nagendra Babu, ${ }^{3}$ Satti Ravindra \\ Kumar $^{3}$ \\ 'Assistant Professor, Department of Pharmaceutics, M.A.M \\ College of Pharmacy, India \\ ${ }^{2}$ Department of Pharmaceutical Analysis, M.A.M College of \\ Pharmacy, India \\ ${ }^{3}$ Department of Pharmaceutics, M.A.M College of Pharmacy, \\ India
}

Correspondence: Raghavendra Kumar Gunda, Assistant Professor, Department of Pharmaceutics, M.A.M college of Pharmacy, Kesanupalli (V), Narasaraopet, Guntur district, AP India-52260I, Tel +91-9666705894,

Email raghav.gund@gmail.com

Received: February 27, 2020 | Published: March 20, 2020
Abbreviations: ODT, oral disintegrating tablet; SD, solid dispersion; PEG, poly ethylene glycol; CP, crospovidone; SSG, sodium starch glycolate; IPQC, in-process quality control; \% CDR, percentage cumulative drug release; RPM, revolutions per minute; BCS, biopharmaceutical classification; UR, unreleased; $t_{10 \%}$, time taken to release $10 \%$ drug from dosage form; $t_{50 \%}$, time taken to release $50 \%$ drug from dosage form; $t_{90 \%}$, time taken to release $90 \%$ drug from dosage form; WT, wetting time; DT, disintegration time dissimilarity factor; $\mathrm{f}_{1}$, dissimilarity factor; $\mathrm{f}_{2}$, similarity factor

\section{Introduction}

Swallowing is troublesome issue in situations like Dysphasia, specifically for both pediatrics and geriatrics. Oral disintegrating tablets created a new benchmark in the pharmaceutical trade. Porous tablets, rapimelts, Oro dispersible tablets, mouth-dissolving tablets, Fast dissolving tablets, quick dissolving, melt-in mouth tablets were used frequently in the place of ODT. ${ }^{1}$

They rapidly disintegrate/dissolve in oral cavity within $(<) 1 \mathrm{~min} .^{2-}$ ${ }^{4}$ They were prepared by various techniques; formed ODTs show differences in sensual characteristics such as mouth feel, swallow ability and taste. They also show variations in product performance like mechanical strength of tablet, drug release, bioavailability \& stability. Manufacturing methods employed for formulating ODTs include mass extrusion, spray drying, cotton candy process, lyophilization, molding, compaction (wet $\&$ dry granulation, direct compression), patented technologies (Durasolv ${ }^{\circledR}$, Orosolv $\left.{ }^{\circledR}\right)^{5-7}$

Lamotrigine is an anti epileptic drug and it is approved in the united states for the treatment of partial seizures and bipolar disease, belongs to class-II under BCS Classification and exhibit oral Bioavailability of about $98 \%$. It is available as immediate release and sustained release formulations in the market with different strengths such as $25 \mathrm{mg}$, 50mg and 100mg. In 2009 GSK received FDA approval for extended release version of Lamotrigine (Lamictal-XR). ${ }^{8-14}$ In the current research investigation the direct compression method was utilized to formulate tablets, due numerous advantages such as simplest and cost effective tablet production method. ${ }^{15}$

\section{Materials and methods}

Lamotrigine was a gift sample procured from Meditech Pharma Pvt Ltd, Hyderabad, India. Mannitol, Crospovidone, Sodium Starch Glycolate were procured from SD Fine Chemicals, Mumbai. Other excipients were procured from LobaChemie Ltd, Mumbai.

\section{A. Formulation development}

Preparation of lamotrigine solid dispersion: PEG 6000 was melted in a beaker on a water bath maintained at $50-60^{\circ} \mathrm{C}$. Required amount (D: E in 1:1) of the drug was then added to molten PEG 6000 and mixed thoroughly for $5 \mathrm{~min}$. The molten mixture was cooled rapidly by placing it in an ice bath for about $5 \mathrm{~min}$ and solidified. The hardened mixture was powdered, sieved through an 80 -mesh screen, packed and stored in desiccators for further processing.

Preparation of lamotrigine fast dissolving tablets: Lamotrigine Tablets were prepared by direct compression method. The formulae presented as Table 1. All ingredients were screened using \#40 and mixed for obtaining uniform fine blends. Lubricants were screened through \#80, mix them with above mixture and compressed to get ODT with the help of Tablet mini press ( 8 station) using $8 \mathrm{~mm}$ circular punches. Obtained tablets were subjected to IPQC tests. Final tablets were transferred to airtight, light resistance containers for storage and further processing. 
Table I Formulae for the preparation of lamotrigine fast dissolving tablets

\begin{tabular}{llllllllll}
\hline \multirow{2}{*}{ Name of Ingredients } & \multicolumn{9}{c}{ Quantity of Ingredients per each Tablet $(\mathbf{m g})$} \\
\cline { 2 - 9 } & FI & F2 & F3 & F4 & F5 & F6 & F7 & F8 & F9 \\
\hline Lamotrigine SD (Complex) & 50 & 50 & 50 & 50 & 50 & 50 & 50 & 50 & 50 \\
Mannitol & 59 & 64 & 69 & 69 & 74 & 79 & 79 & 84 & 89 \\
Crospovidone & 50 & 50 & 50 & 40 & 40 & 40 & 30 & 30 & 30 \\
Sodium starch glycolate & 35 & 30 & 25 & 35 & 30 & 25 & 35 & 30 & 25 \\
Colloidal Silicone dioxide & 3 & 3 & 3 & 3 & 3 & 3 & 3 & 3 & 3 \\
Magnesium Stearate & 3 & 3 & 3 & 3 & 3 & 3 & 3 & 3 & 3 \\
Total Weight & 200 & 200 & 200 & 200 & 200 & 200 & 200 & 200 & 200 \\
\hline
\end{tabular}

\section{B. Evaluation of lamotrigine fast dissolving tablets}

Hardness: It was carried out with the help of Monsanto Tablet Hardness Tester. ${ }^{16}$

Friability: The friability of the tablets was determined with the help of Roche Friabilator. Weight of 20 Tablets noted as Initial weight $\left(\mathrm{W}_{0}\right.$ ) are dedusted in a drum for 4 min with a rotation rate of $25 \mathrm{rpm}$ and weight was noted as Final weight (W). Percentage friability was determined from following equation. The weight loss should not be more than $1 \%{ }^{16}$

$$
\text { Friability }(\%)=\left(\mathrm{W}_{0}-\mathrm{W}\right) / \mathrm{W}_{0} \times 100
$$

Content uniformity: 20 tablets were randomly selected and the percent drug content was determined, the tablets contained not less than $92.5 \%$ or not more than $107.5 \%(100 \pm 7.5 \%)$ of the labeled drug content can be considered as the test was passed. ${ }^{9,17}$

Assay: Select fixed number of sample on the random basis (20), comminute them to a obtain powder. The powder equivalent to $100 \mathrm{mg}$ Lamotrigine was weighed and transferred to $100 \mathrm{~mL}$ volumetric flask containing $60 \mathrm{~mL}$ of methanol and sonicated for $10 \mathrm{~min}$ to solubilize the drug completely then dilute the methanolic solution with water to make up the final volume. From that prepare further dilution of $2 \mathrm{~mL}$ aliquot in $100 \mathrm{~mL}$ of $0.1 \mathrm{~N} \mathrm{HCl}$. The obtained solution was filtered through Whatman filter paper and absorbance of solution as measured at $254 \mathrm{~nm}$ with the help of UV-Visible spectrophotometer.

Thickness: Thickness was determined with the help vernier calipers. ${ }^{18}$

Wetting time: To measure Wetting time of the Tablet, a piece of Tissue paper folded twice was placed in a small petri dish (Internal Diameter is $=6.5 \mathrm{~cm}$ ) containing $5 \mathrm{ml}$ of Distilled water. A Tablet placed on the paper, and the time for complete wetting of the tablet was measured in sec. ${ }^{15-18}$

In-vitro Dissolution Study: Lamotrigine oral disintegrating tablets subjected to dissolution test with the help of USP XXIII type-II tablet dissolution test apparatus using $900 \mathrm{ml}$ of $0.1 \mathrm{~N} \mathrm{HCl}$ operated under standard set of conditions. Withdraw samples at fixed intervals with the aid of syringe with a pre-filter, and maintain the sink condition. Absorbance for samples was noted at $254 \mathrm{~nm}$ using UV Visible spectrophotometer (after suitable dilutions if necessary). The determinations were performed in triplicate $(n=3) .{ }^{9}$

Disintegration test: Disintegration of oral disintegrating tablets is achieved in the oral cavity owing to the impact of saliva, salivary volume is limited hence there is no proper In vitro and In vivo correlation (IVIVC) was found in USP and IP. A modified method was used to determine to perform the disintegration test. A cylindrical vessel with $10 \#$ was placed in such way that only $2 \mathrm{ml}$ of medium would be placed below the sieve. $6 \mathrm{ml}$ of medium was placed inside the vessel in such way that $4 \mathrm{ml}$ of the media was below the sieve and $2 \mathrm{ml}$ above the sieve. Tablet was placed on the sieve and the whole assembly was then placed on the top of agitator. Disintegration time was recorded. Six tablets were chosen randomly from the composite samples and the average value was determined. ${ }^{18}$

Kinetic modeling of drug release: The dissolution profile of all the formulations was subjected to kinetic modeling. ${ }^{19-23}$

\section{Results and discussion}

9 Lamotrigine Oral Disintegrating Tablet Formulations were prepared by direct compression method using various proportions of super disintegrants combination as per the formulae presented in Table 1. All the formulations containing $25 \mathrm{mg}$ of Lamotrigine (as Lamotrigine SD with PEG as 1:1 ratio) prepared tablets prepared and evaluated for various pharmacopoeias limits such as, drug content, mean hardness, friability, mean thickness, Weight variation as per official methods. The Thickness values were found in the range from $3.15 \pm 0.02 \mathrm{~mm}$ to $3.23 \pm 0.02 \mathrm{~mm}$. Uniformity in the values indicates that formulations were compressed without sticking to the dies and punches. Hardness was maintained to be within $3.85 \pm 0.21 \mathrm{Kg} / \mathrm{cm}^{2}$ to $4.1 \pm 0.3 \mathrm{Kg} / \mathrm{cm}^{2}$. The hardness of all batches was almost uniform and possesses good mechanical strength. The study results for friability were found well within the approved range $(<0.66 \%)$ in all the formulation. Results revealed that the tablets possess good mechanical strength.

All the tablets passed weight variation test as the \% weight variation was within the pharmacopoeias limits of $\pm 5 \%$. Average weight for all formulations was found to be in the range of $198.17 \pm 0.55-200.84 \pm 0.76 \mathrm{mg}$. This is due to good flow property and compressibility of all the formulations.

From the results of wetting time and Disintegration time, it reveals that as the concentration of super disinterants increases the wetting time decreases (Concentration of super disintegrants inversely proportional to wetting time). Wetting time for all the formulations varied from $23.11 \pm 2.3$ to $30.5 \pm 1.81 \mathrm{sec}$. The Disintegration Time of tablets was in the range of $22.5 \pm 1.7-35.5 \pm 1.34 \mathrm{sec}$. 
Results for all Post-compression parameters were tabulated or shown in Table 2 and plots for wetting time and disintegration were presented in Figure1\&2. The cumulative percentage drug released by each tablet in the In Vitro Release studies were based on the mean content of the drug present in the respective tablet.

Cumulative \% Drug release for $\mathrm{F}_{1}-\mathrm{F}_{9}$ at $60 \mathrm{~min}$ was found to be in the range of $99.21 \pm 0.66-99.84 \pm 0.01 \%$. Dissolution profiles of Lamotrigine oral disintegrating formulations were subjected to goodness of fit test by linear regression analysis according to kinetic modeling to ascertain the drug release mechanism. The statistical parameters for kinetic models were determined and data present as Table 3 and plots represented as figure 3-6. The values of $r$ for formulations regarding Higuchi's kinetics within a range of 0.9880.997, Kinetic data also treated for Peppas equation, the slope (n) values ranges from 0.492-0.643 that shows Non-Fickian diffusion mechanism. Formulation $\mathrm{F}_{4}$ containing $40 \mathrm{mg}$ of Crospovidone, $35 \mathrm{mg}$ of Sodium Starch Glycolate exerted promising dissolution parameter (Wetting time $=24.5 \pm 1.8 \mathrm{sec}$, Disintegrating time $=29 \pm 1.54 \mathrm{sec}$, $\mathrm{t}_{10 \%}=0.926 \mathrm{~min}, \mathrm{t}_{50 \%}=6.091 \mathrm{~min}, \mathrm{t}_{90 \%}=20.240 \mathrm{~min}$ ). Results for Kinetic parameters were presented in Table 4. The final best Formulation $\mathrm{F}_{4}$ is compared with Marketed product (LAMICTAL-25) tablets and Comparative Dissolution profiles shown in figure 7. Which shows similarity $\left(f_{2}=73.17, f_{1}=3.65\right)$.

Table 2 Post-compression parameters

\begin{tabular}{|c|c|c|c|c|c|c|c|c|}
\hline S. No & $\begin{array}{l}\text { Formulation } \\
\text { Code }\end{array}$ & $\begin{array}{l}\text { Hardness } \\
(\mathrm{kg} / \mathrm{cm} 2)\end{array}$ & $\begin{array}{l}\text { Thickness } \\
\text { (mm) }\end{array}$ & $\begin{array}{l}\text { Friability } \\
(\%)\end{array}$ & $\begin{array}{l}\text { Avg wt } \\
\text { (mg) }\end{array}$ & $\begin{array}{l}\text { Drug } \\
\text { Content (\%) }\end{array}$ & $\begin{array}{l}\text { Wetting } \\
\text { time (sec) }\end{array}$ & $\begin{array}{l}\text { Disintegration } \\
\text { time (sec) }\end{array}$ \\
\hline I & $\mathrm{FI}$ & $4.05 \pm 0.25$ & $3.18 \pm 0.02$ & $0.54 \pm 0.6$ & $199.23 \pm 0.45$ & $98.3 \pm 1.16$ & $23.11 \pm 2.30$ & $27.5 \pm 1.76$ \\
\hline 2 & $\mathrm{~F} 2$ & $3.9 \pm 0.2$ & $3.15 \pm 0.02$ & $0.6 \mathrm{I} \pm 0.38$ & $199.84 \pm 0.95$ & $98.8 \pm 2.04$ & $24.5 \pm 2.26$ & $29 \pm 2.52$ \\
\hline 3 & $\mathrm{~F} 3$ & $4.05 \pm 0.25$ & $3.19 \pm 0.023$ & $0.65 \pm 0.28$ & $198.17 \pm 0.55$ & $98.04 \pm 1.64$ & $26.5 \pm 2.02$ & $31.5 \pm 2.03$ \\
\hline 4 & $\mathrm{~F} 4$ & $4.09 \pm 0.265$ & $3.19 \pm 0.013$ & $0.62 \pm 0.19$ & $200.05 \pm I . I$ & $99.74 \pm \mid .31$ & $24.5 \pm 1.8$ & $29 \pm 1.54$ \\
\hline 5 & F5 & $3.85 \pm 0.215$ & $3.16 \pm 0.013$ & $0.54 \pm 0.28$ & $200.12 \pm 0.54$ & $99.24 \pm 2.18$ & $26 \pm 1.76$ & $30.5 \pm 2.3$ \\
\hline 6 & F6 & $4 \pm 0.265$ & $3.2 \pm 0.016$ & $0.63 \pm 0.07$ & $199.17 \pm 0.89$ & $98.48 \pm 1.79$ & $28 \pm 1.53$ & $33 \pm 1.81$ \\
\hline 7 & $\mathrm{~F} 7$ & $4.1 \pm 0.3$ & $3.22 \pm 0.015$ & $0.62 \pm 0.4$ & $200.84 \pm 0.76$ & $99.2 \pm 1.6$ & $27 \pm 2.08$ & $31.5 \pm 1.1$ \\
\hline 8 & F8 & $3.95 \pm 0.25$ & $3.19 \pm 0.015$ & $0.56 \pm 0.4$ & $200.83 \pm 0.15$ & $99.7 \pm 2.48$ & $28.5 \pm 2.04$ & $33 \pm 1.84$ \\
\hline 9 & F9 & $4.1 \pm 0.3$ & $3.23 \pm 0.018$ & $0.61 \pm 0.39$ & $200.26 \pm 0.44$ & $98.94 \pm 2.08$ & $30.5 \pm 1.81$ & $35.5 \pm 1.34$ \\
\hline
\end{tabular}

Table 3 Statistical parameters

\begin{tabular}{|c|c|c|c|c|c|c|c|c|c|c|c|c|c|}
\hline \multirow[t]{3}{*}{ S. No } & \multirow{3}{*}{$\begin{array}{l}\text { Formulation } \\
\text { Code }\end{array}$} & \multicolumn{12}{|c|}{ Kinetic parameters } \\
\hline & & \multicolumn{3}{|c|}{ Zero order } & \multicolumn{3}{|c|}{ First order } & \multicolumn{3}{|c|}{ Higuchi } & \multicolumn{3}{|c|}{$\begin{array}{l}\text { Korsmeyer- } \\
\text { peppas }\end{array}$} \\
\hline & & $\mathbf{a}$ & b & $\mathbf{r}$ & $\mathbf{a}$ & b & $\mathbf{r}$ & $\mathbf{a}$ & b & $\mathbf{r}$ & $\mathbf{a}$ & b & $\mathbf{r}$ \\
\hline I & $\mathrm{FI}$ & 19.656 & 1.569 & 0.941 & 2.269 & 0.04 & 0.936 & 0.669 & 13.499 & 0.996 & 1.132 & 0.502 & 0.992 \\
\hline 2 & $\mathrm{~F} 2$ & 18.699 & 1.575 & 0.945 & 2.258 & 0.038 & 0.931 & 0.079 & 13.495 & 0.996 & 1.092 & 0.525 & 0.993 \\
\hline 3 & F3 & 15.612 & $\mathrm{I} .574$ & 0.962 & 2.212 & 0.032 & 0.929 & 2.046 & 13.258 & 0.997 & 1.009 & 0.564 & 0.996 \\
\hline 4 & $\mathrm{~F} 4$ & 18.783 & 1.634 & 0.938 & 2.341 & 0.049 & 0.966 & 0.726 & 14.006 & 0.989 & 1.059 & 0.554 & 0.982 \\
\hline 5 & F5 & 17.894 & 1.637 & 0.941 & 2.217 & 0.04 & 0.977 & 1.403 & 13.978 & 0.988 & 1.017 & 0.577 & 0.982 \\
\hline 6 & F6 & 14.757 & 1.638 & 0.959 & 2.225 & 0.035 & 0.961 & 3.422 & 13.76 & 0.991 & 0.928 & 0.621 & 0.989 \\
\hline 7 & F7 & 15.3 & 1.604 & 0.963 & 2.251 & 0.035 & 0.944 & 2.486 & 13.472 & 0.995 & 1.004 & 0.57 & 0.994 \\
\hline 8 & F8 & 14.334 & 1.612 & 0.967 & 2.242 & 0.034 & 0.943 & 3.256 & 13.48 & 0.995 & 0.957 & 0.597 & 0.996 \\
\hline 9 & F9 & 11.223 & 1.612 & 0.98 & 2.238 & 0.031 & 0.922 & 5.242 & 13.247 & 0.991 & 0.863 & 0.643 & 0.995 \\
\hline 10 & Lamictal-25 & 21.116 & 1.57 & 0.925 & 2.415 & 0.051 & 0.879 & 1.504 & 13.635 & 0.988 & 1.156 & 0.492 & 0.975 \\
\hline
\end{tabular}


Table 4 Dissolution/ kinetic parameters

\begin{tabular}{lllll}
\hline S. No & Formulation code & \multicolumn{2}{l}{ Kinetic parameters } \\
& & $\mathbf{t}^{1 / 2}(\mathbf{m i n})$ & $\mathbf{t} 1 \mathbf{0} \%(\mathbf{m i n})$ & $\mathbf{t 9 0 \%}(\mathbf{m i n})$ \\
\hline I & FI & 7.547 & 1.147 & 25.08 \\
2 & F2 & 7.873 & 1.197 & 26.162 \\
3 & F3 & 9.364 & 1.423 & 31.117 \\
4 & F4 & 6.091 & 0.926 & 20.24 \\
5 & F5 & 7.588 & 1.153 & 25.217 \\
6 & F6 & 8.664 & 1.317 & 28.79 \\
7 & F7 & 8.484 & 1.29 & 28.192 \\
8 & F8 & 8.797 & 1.337 & 29.232 \\
9 & F9 & 9.668 & 1.47 & 32.127 \\
10 & Lamictal-25 & 5.914 & 0.899 & 19.653 \\
\hline
\end{tabular}

\section{Wetting Time Chart}

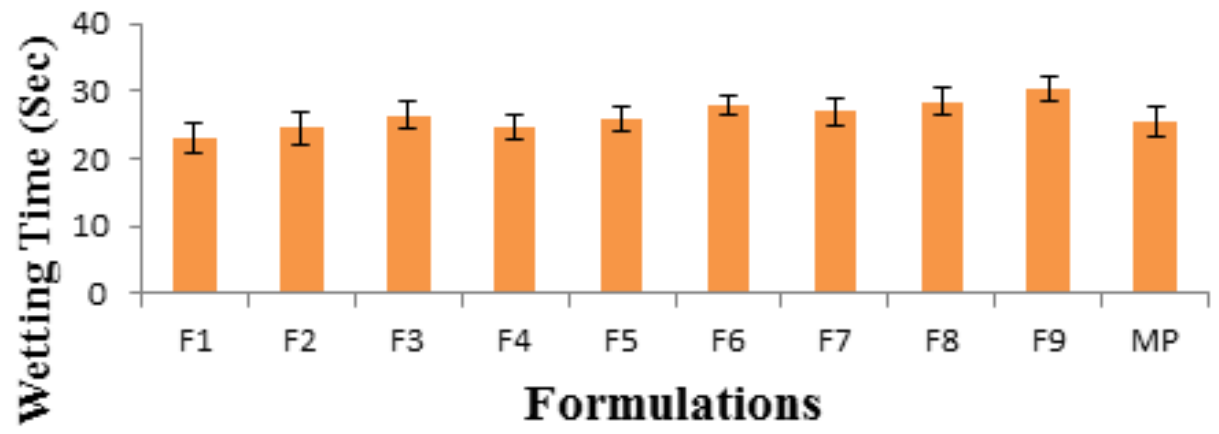

Figure I Wetting time chart.

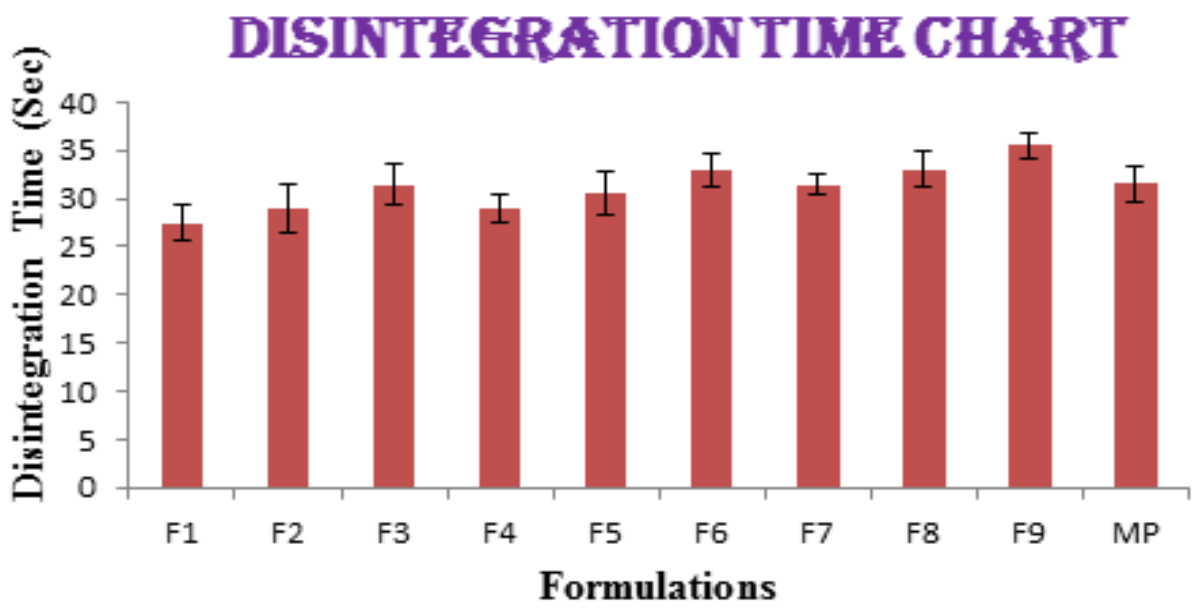

Figure 2 Disintegration time chart. 


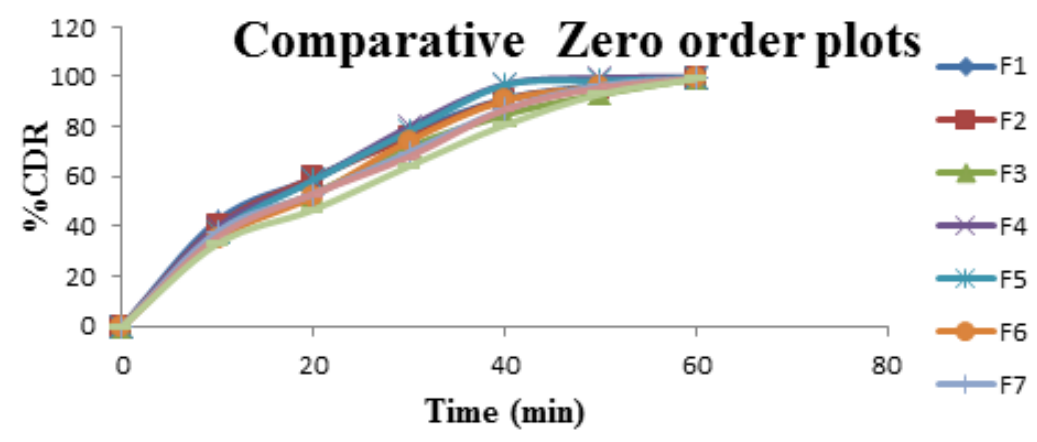

Figure 3 Comparative zero order plots.

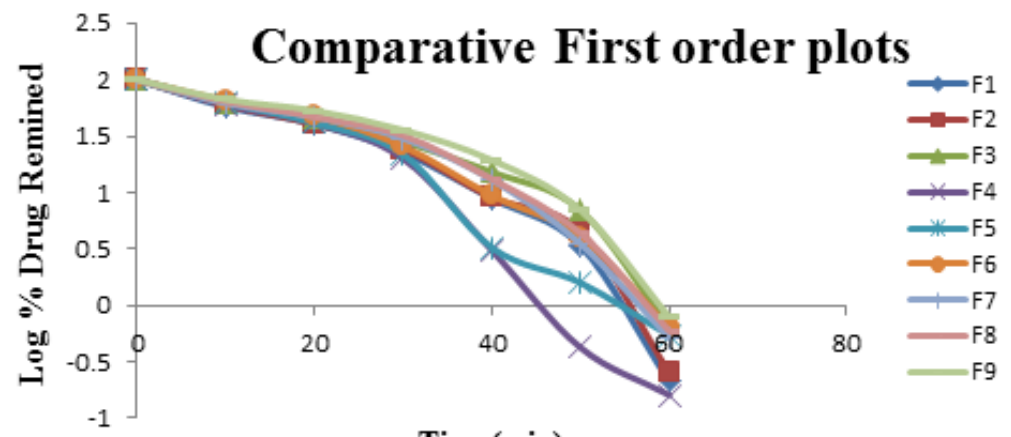

Time(min)

Figure 4 Comparative first order plots.

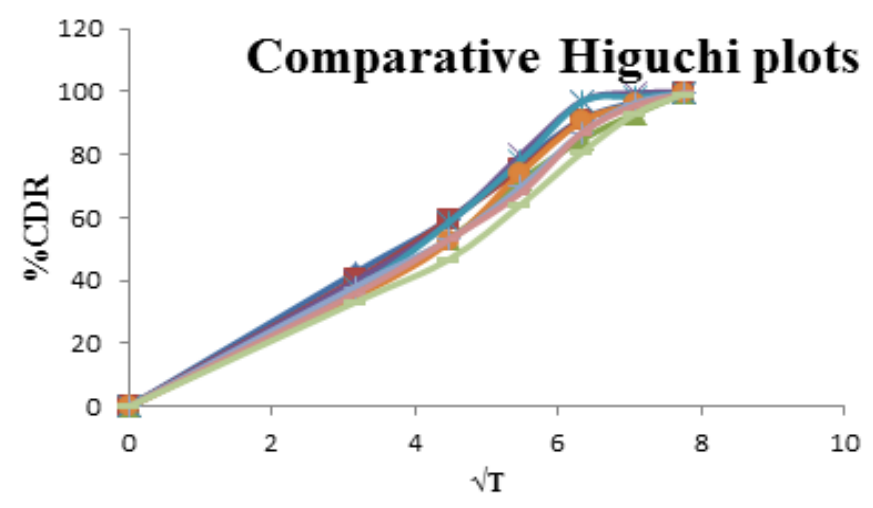

Figure 5 Comparative higuchi plots.

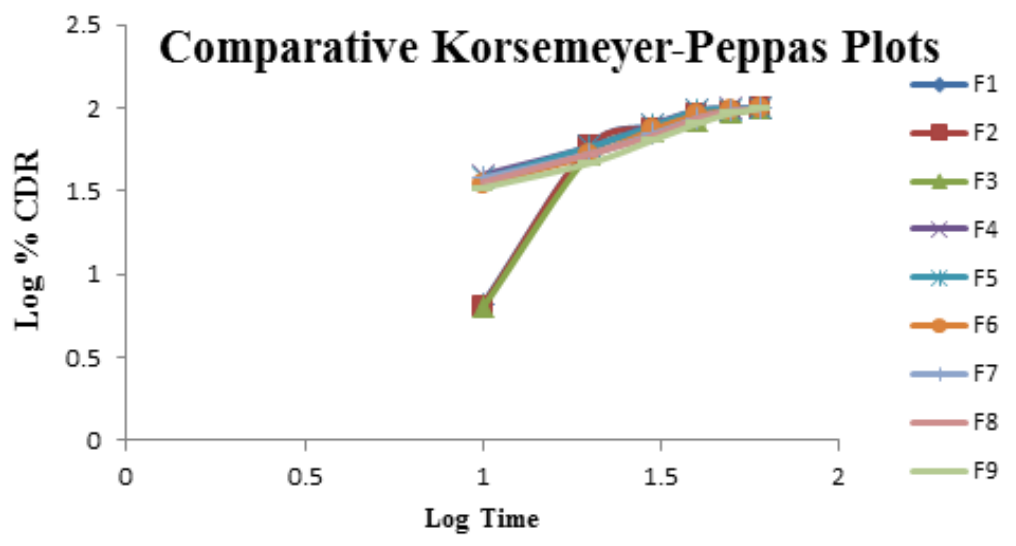

Figure 6 Comparative Korsmeyer-Peppas plots. 


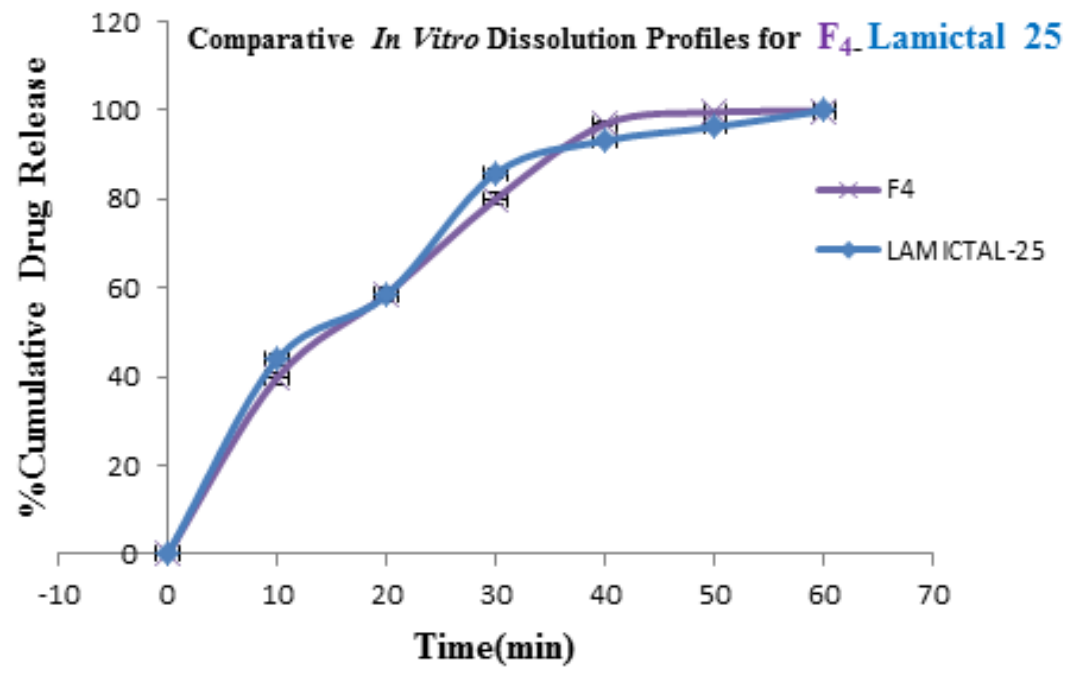

Figure 7 Comparative in-vitro Dissolution Profiles of $F_{4}$, lamictal.

\section{Conclusion}

The current research investigation focuses about influence of utilization of super disintegrants such as Crospovidone and Sodium Starch Glycolate in the formulation development of oral disintegrating tablet formulations of Lamotrigine. Results reveals that quantities of Super disintegrants shows good impact on release of drug from formulation (directly proportional) The optimized formulation followed Higuchi's kinetics while the drug release mechanism was found to be Non-Fickian Diffusion, first order release type. On the basis of evaluation parameters, the optimized formulation $\mathrm{F}_{5}$ may be used for the effective management of Epilepsy, convulsions. This may improve the patient compliance by showing rapid action via disintegration without difficult in swallowing and side effects which will ultimately improve the therapeutic outcome. We could be able to minimize the oral cost of the formulation.

\section{Acknowledgments}

The author would like to thank the Management, Principal and Staff of M.A.M college of Pharmacy, Kesanupalli, Narasaraopet, Guntur district, AP, India providing support for successful completion of research work.

\section{Conflicts of interest}

The author declares that there are no conflicts of interest.

\section{Funding}

None.

\section{References}

1. K Kavitha, KumuthaSubramaniam, BoeyJiaHui, et al. Potential Drug Candidates for Fast Dissolving Drug Delivery - A Review. Res J Pharm Bio Chem Sci. 2013;4(4):1510-1526.

2. Sehgal P, Gupta R, Umesh Kumar S, et al. Fast Dissolving Tablets: A New Venture in Drug Delivery. Amer J Pharm Tech Res. 2012; 2(4):252-279.
3. Raghavendra Kumar Gunda JN, Suresh Kumar, S Jayakumari, et al. Formulation Development and Evaluation of Risperidone Fast Dissolving Tablets. J Pharm Res. 2010; 10(9): 579-588.

4. David E, Armen HT, Ethrin JA, et al. Principles of pharmacology: The pathophysiologic basis of drug therapy. New Delhi: Wolters Kluwer (India) Pvt Ltd. 2008:815.

5. Rajeev soni, Galividyasagar. Design and development of quick dissolving tablet Containing loratadine by direct compression method. Int J Pharm Chem Bio Sci. 2013;3(3):771-800.

6. Gupta A, Mishra AK, Gupta V, et al. Recent Trends of Fast Dissolving Tablet - An Overview of Formulation Technology. Int J Pharm Bio Arch. 2010;1(1):1-10.

7. Manivannan R. Oral Disintegrating Tablets: A Future Compaction. Int J Pharm Res Dev. 2009;1(1):1-10.

8. Mladena L, Ana P, Svetlene GK, et al. Comparison of Dissolution Profiles and Serum Concentrations of two Lamotrigine tablet formulations. Drugs in $R \&$ D. 2011;11(1):53-60.

9. Gunda RK, Kumar JNS, Babu CA, et al. Formulation Development and Evaluation of Lamotrigine Sustained Release Tablets Using 32 Factorial Design. Int J Pharm Sci Res. 2015;6(4):1746-1752.

10. Koteswari P, Sunium S, Srinivasababu P, et al. Formulation Development and evaluation of fast disintegrating tablets of Lamotrigine using liquisolid technique. Int J Pharm Investig. 2014;4(4):207-214.

11. Madhuri T Hivarkar, Ravi D Hole. Formulation and Evaluation of Fast Dissolving Tablet of Lamotrigine. Int J Pharm Res Sch. 2018;7(2):5057.

12. Lakshmi PK, Swetha Reddy, Kishore C, et al. Formulation and Evaluation of Oral Disintegrating Tablets of Lamotrigine Solid Dispersions. Iran J Pharm Sci. 2013:9(1):1-12.

13. Mohan A, Gundamaraju R. In vitro and In vivo evaluation of fastdissolving tablets containing solid dispersion of Lamotrigine. Int $J$ Pharm Investig. 2015;5(1):57-64.

14. Jatinderpal Singh, Rajeev Garg, Ghanshyam Das Gupta. Enhancement of Solubility of Lamotrigine by Solid Dispersion and Development of Orally Disintegrating Tablets Using $3^{2}$ Full Factorial Designs. J Pharm. 2015:1-8. 
15. Raghavendra Kumar Gunda, Prasada Rao Manchineni, Chaikam Gopi Reddy, et al. Formulation development and in vitro evaluation of oral disintegrating tablets for newer anticonvulsant agent. J Anal Pharm Res. 2019;8(2):85-89.

16. Gunda Raghavendra Kumar, Suresh Kumar JN, Satyanarayana V, et al. Formulation Development and Evaluation of Clopidogrel Fast Dissolving Tablets. Iran J Pharm Sci. 2016;12(2):61-74.

17. Raghavendra Kumar Gunda, Jujjuru Naga Suresh Kumar. Formulation Development and Evaluation of Moxifloxacin $\mathrm{HCl}$ Fast Dissolving Tablets. Pharm Meth. 2017;8(2):160-167.

18. Raghavendra Kumar Gunda, Suresh Kumar JN, Satyanarayana V, et al. Formulation Development and Evaluation of Carbamazepine Fast Dissolving Tablets. J Pharm Res. 2016;10(5):216-225.
19. Raghavendra Kumar Gunda, Vijayalakshmi A. Formulation Development and Evaluation of Gastro retentive Bio adhesive drug delivery system for Moxifloxacin HCL. Ind J Pharm Edu Res. 2019;53(4):724-732.

20. Larry A Bauer. Biopharmaceutics and clinical pharmacokinetics. 4th edn. New York: Journal of Pharmaceutical sciences. 1987;76(2):6-21.

21. Higuchi T. Mechanism of sustained-action medication. Theoretical analysis of rate of release of solid drugs dispersed in solid matrices. $J$ Pharm Sci. 1963;52(12):1145-1149.

22. Raghavendra Kumar Gunda, Jujjuru Naga Suresh Kumar. Formulation Development and Evaluation of Amisulpride Fast Dissolving Tablets. FABAD J Pharm Sci. 2018;43(2):105-115.

23. Peppas NA. Analysis of fickian and non-fickian drug release from polymers. Pharmaceutica Acta Helvetiae. 1985;60:110-111. 